\title{
Benturan Kepentingan Transaksi Tertentu di Pasar Modal
}

\author{
Siti Anisah
}

\begin{abstract}
To avoid the interest conflict on certain transaction, the major agreement of independent share holder must be put into in action. The reality, many kinds of disobeying on the agreement are found. The law enforcement by Money Market Supervisor as the highest authority in the Money Market has not been maximal and it tends to be unjust to the parties on certain transactional conflict.
\end{abstract}

\section{Pendahuluan}

Transaksi yang mengandung benturan kepentingan berpotensi merugikan salah satu pihak, karena adanya unsur kolusi dan pelanggaran prinsip keterbukaan informasi. ${ }^{1}$ Untuk menghindari kerugian akibat transaksi tersebut, Badan Pengawas Pasar Modal dapat mewajibkan emiten dan perusahaan publik untuk memperoleh persetujuan mayoritas pemegang saham independèn. ${ }^{2}$ Keharusan persetujuan pemegang saham independen dipertegas kembali dalam Peraturan Badan Pengawas Pasar Modal Nomor IX.E.1 tentang Benturan Kepentingan Transaksi Tertentu.

Implementasi ketentuan tersebut mengindikasikan Badan Pengawas Pasar Modal masih terkesan kurang tegas dalam menegakkan peraturan tentang benturan kepentingan transaksi tertentu di pasar modal. Hal ini antara lain dapat dilihat dari kesamaan besarnya sanksi yang diberikan kepada perusahaan yang melanggar ketentuan tersebut, padahal nilai nominal pelanggaran yang dilakukan sangat bervariasi. Hal lainnya, tidak semua direksi maupun komisaris yang terlibat benturan kepentingan transaksi tertentu dikenakan sanksi. Untuk itu, bagaimana

$1 \mathrm{M}$. Irsan Nasarudin dan Indra Surya, Aspek Hukum Pasar Modallndonesia (Jakarta: Prenada Media, 2004), hlm 241. Prinsip keterbukaan informasi merupakan jiwa pasar modal. Lebih lanjut lihat Bismar Nasution, Keterbukaan dalam Pasar Modal (Jakarta: Fakultas Hukum, Program Pascasarjana Universitas Indonesia, 2001), hlm 1.

2 Pasal 82 ayat (2) Undang-Undang Nomor 8 Tahun 1995 tentang Pasar Modal. 
perlindungan hukum terhadap pemegang saham independen berkaitan dengan benturan kepentingan transaksi tertentu, dan bagaimana penegakan hukum benturan kepentingan transaksi tertentu di pasar modal? Apakah sanksi yang dijatuhkan Badan Pengawas Pasar Modal sesuai dengan ketentuan yang berlaku?

\section{Ketentuan Suatu Transaksi yang Mengandung Benturan Kepentingan}

Ketentuan khusus yang mengatur suatu transaksi yang mengandung benturan kepentingan adalah Peraturan Nomor IX.E.1 tentang Benturan Kepentingan Transaksi Tertentu. Ketentuan ini merupakan peraturan pelaksanaan dari Pasal 82 ayat (2) UndangUndang Nomor 8 Tahun 1995 tentang Pasar Modal. Ketentuan tersebut telah mengalami beberapa kali perubahan yaitu pertama, Keputusan Ketua Badan Pengawas Pasar Modal Nomor Kep-84/PM/1996, diubah dengan Kep-12/PM/1997, selanjutnya diubah dengan Keputusan Ketua Badan Pengawas Pasar Modal Nomor Kep-32/PM/2000 tentang Perubahan Peraturan Nomor IX.E.1 tentang
Benturan Kepentingan Transaksi Tertentu. ${ }^{3}$

Secara prinsip peraturan tersebut mempunyai tujuan untuk: ${ }^{4}$

1. melindungi kepentingan pemegang saham independen yang pada umumnya merupakan pemegang saham minoritas dari perbuatan yang melampaui kewenangan direksi, komisaris, dan pemegang saham utama dalam melakukan transaksi yang mengandung benturan kepentingan tertentu.

2. mengurangi kemungkinan penyalahgunaan kekuasaan oleh direksi, komisaris, atau pemegang saham utama untuk melakukan transaksi yang mengandung benturan kepentingan tertentu.

3. melaksanakan prinsip keterbukaan dan penghormatan terhadap hak pemegang saham berdasarkan asas kesetaraan, persetujuan pemegang saham independen yang mewakili lebih dari $50 \%$ saham yang merupakan keharusan.

Badan Pengawas Pasar Modal dapat mewajibkan Emiten atau Perusahaan Publik untuk memperoleh mayoritas persetujuan pemegang saham independen apabila Emiten

${ }^{3}$ Selanjutnya disebut Peraturan Nomor IX.E.1. Perubahan yang terakhir ini antara lain dimaksudkan untuk memperluas pengertian Benturan Kepentingan dan pengertian Pemegang Saham Independen, dengan harapan dapat lebih mempermudah penentuan Pihak yang berhak hadir dan memberikan hak suara dalam Rapat Umum Pemegang Saham Independen apabila terdapat suatu transaksi yang mempunyai Benturan Kepentingan, sehingga perlindungan kepada pemegang saham, khususnya pemegang saham independen, menjadi lebih meningkat. Penyempurnaan peraturan ini juga merupakan penyelarasan dengan ketentuan tentang Transaksi Material dan Perubahan Kegiatan Usaha Utama serta peraturan tentang Pengambilalihan Perusahaan Terbuka. Hal lain yang mendorong penyempumaan Peraturan Nomor IX.E.1 adalah untuk membantu proses pemulihan ekonomi nasional, termasuk upaya restrukturisasi perusahaan. Lihat Badan Pengawas Pasar. Modal, "Press Release Penyempurnaan Peraturan Bapepam tentang Benturan Kepentingan Transaksi Tertentu" http://www.bapepam.go.id/news/Agutus2000/PR_23_08.htm, 23 Agustus 2000.

${ }^{4} \mathrm{M}$. Irsan Nasarudin dan Indra Surya, op. cit., hlm 242. 
atau Perusahaan Publik tersebut melakukan transaksi di mana kepentingan ekonomis Emiten atau Perusahaan Publik tersebut berbenturan dengan kepentingan ekonomis pribadi direktur, komisaris, atau pemegang saham utama Emiten atau Perusahaan Publik dimaksud. ${ }^{5}$

Kata "dapat mewajibkan" yang dapat diartikan bukan suatu keharusan dalam Pasal 82 ayat (2) Undang-Undang Nomor 8 Tahun 1995 tentang Pasar Modal, dipertegas menjadi "keharusan" dalam Peraturan Nomor IX.E.1, yaitu "Jika suatu transaksi dimana direktur, komisaris, pemegang saham utama atau pihak terafiliasi dari direktur, komisaris atau pemegang saham utama mempunyai benturan kepentingan, maka transaksi dimaksud terlebih dahulu harus disetujui oleh para pemegang saham independen atau wakil mereka yang diberi wewenang untuk itu dalam Rapat Umum Pemegang Saham." Persetujuan mengenai hal tersebut harus ditegaskan dalam bentuk akta notariil. ${ }^{6}$

Selanjutnya transaksi diartikan sebagai aktivitas atau kontrak dalam rangka memberikan dan atau mendapat pinjaman, memperoleh, melepaskan atau menggunakan aktiva, jasa atau Efek suatu perusahaan atau perusahaan terkendali atau mengadakan kontrak sehubungan dengan aktivitas tersebut. ${ }^{7}$ Sedangkan benturan kepentingan ${ }^{8}$ adalah perbedaan antara kepentingan ekonomis Perusahaan dengan kepentingan ekonomis pribadi direktur, komisaris, pemegang saham utama perusahaan atau pihak terafiliasi ${ }^{9}$ dari direktur,

\section{${ }^{5}$ Pasal 82 ayat (2) Undang-Undang Nomor 8 Tahun 1995 tentang Pasar Modal.}

${ }^{6}$ Lihat Pasal 2 Peraturan Nomor IX.E. 1. Lihat pula Pasal 1 huruf e yang menyebutkan Pemegang Saham Independen adalah pemegang saham yang tidak mempunyai Bentuan Kepentingan sehubungan dengan suatu Transaksi tertentu dan atau bukan merupakan Pihak Terafiliasi dari direktur, komisaris atau Pemegang Saham Utama yang mempunyai Benturan Kepentingan atas transaksi tertentu.

7. Lihat Pasal 1 huruf $\mathrm{c}$ Peraturan Nomor IX.E.1. Lihat pula Pasal 1 huruf b yang menyatakan Perusahaan Terkendali adalah suatu Perusahaan yang dikendalikan baik secara langsung maupun tidak langsung oleh Perusahaan.

${ }^{8}$ Benturan kepentingan dapat pula diartikan sebagai conflict of interest. Lihat M. Irsan Nasarudin dan Indra Surya, op. cit., hlm 241. Wall Street Dictionary mendefinisikan conflict of interest (konflik kepentingan) adalah seseorang yang seharusnya objektif atau tidak berpihak dalam sebuah transaksi, menempatkan kepentingan dirinya sendiri di atas kepentingan pelanggannya, dengan cara mengambil posisi yang akan menguntungkan dirinya. Misalnya, seorang pejabat pemerintah yang mempunyai saham pada sebuah perusahaan, mendukung pemberian fasilitas khusus terhadap perusahaan tersebut. Lihat R.J. Shook, "Wall Street Dictionary", Alih Bahasa Roy Sembel, Kamus Lengkap Keuangan Wall Street (Jakarta: Eflangga, 2002), him 101. Robert Charles Clark mengelompokkan berbagai konflik kepentingan ke dalam empat kelompok atau disebut dengan the four paradigms of conflict of interest, yaitu: basic self dialing, executive compensation, the taking of corporate or shareholder property, dan corporate action with mixed motive. Lihat Paripurna P. Sugarda, "Pengelolaan Perusahaan yang Baik: Apakah Hanya Etika Bisnis Atau Juga Persyaratan Hukum?" Jumal Hukum Bisnis (Jakarta: Yayasan Pengembangan Hukum Bisnis, Juli 2001), hlm 56.

${ }^{8}$ Pasal 1 angka 23 Undang-Undang Nomor 8 Tahun 1995 tentang Pasar Modal menyebutkan pihak adalah orang perseorangan, perusahaan usaha bersama, asosiasi, atau kelompok yang terorganisasi. Pasal 
komisaris atau pemegang saham utama. ${ }^{10}$ Transaksi yang dikecualikan dari ketentuan transaksi yang mempunyai benturan kepentingan adalah:"11

1. Transaksi antara perusahaan dengan perusahaan terkendali yang saham atau modalnya dimiliki sekurang-kurangnya $99 \%$ atau antara sesama perusahaan terkendali yang saham atau modalnya dimiliki minimal $99 \%$ oleh perusahaan tersebut, jika laporan keuangan perusahaan tersebut dikonsolidasikan;

2. transaksi antara perusahaan dengan perusahaan terkendali yang saham atau modalnya tidak dimiliki seluruhnya dan tidak satu pun saham atau modal perusahaan terkendali dimiliki oleh komisaris, direktur, pemegang saham utama perusahaan tersebut, atau pihak terafiliasinya. Jika pemilik saham pada perusahaan terkendali tersebut melebihi $50 \%$, maka laporan keuangan harus dikonsolidasikan;

3. transaksi yang melibatkan perusahaan atau perusahaan terkendali dengan pihak terafiliasi, jika: a. hubungan dan jenis transaksi sudah ada sebelum perusahaan dimaksud mengadakan penawaran umum dan hubungan ini bersifat hubungan yang berlanjut, telah diungkapkan sepenuhnya dalam prospektus penawaran perdana tersebut; atau

b. hubungan dan jenis transaksi yang dimulai sesudah penawaran umum, yang telah memperoleh persetujuan pemegang saham independen yang mewakili lebih dari $50 \%$ saham yang dimiliki pemegang saham independen;

4. transaksi antara perusahaan, baik dengan karyawan, direksi atau komisaris perusahaan tersebut maupun dengan karyawan, direksi atau komisaris perusahaan terkendali, dan transaksi antara perusahaan terkendali baik dengan karyawan, direksi atau komisaris perusahaan terkendali tersebut maupun dengan karyawan, direksi atau komisaris perusahaan dengan persyaratan yang sama, sepanjang hal tersebut diungkapkan kepada Badan Pengawas

1 angka 1 undang-undang yang sama menentukan afiliasi adalah (a) hubungan keluarga karena perkawinan atau keturunan sampai derajat kedua, baik secara horizontal maupun vertikal; (b) hubungan antara pihak dengan pegawai, direktur, atau komisaris dari pihak tersebut; (c) hubungan antara 2 perusahaan di mana terdapat satu atau lebih anggota direksi atau dewan komisaris yang sama; (d) hubungan antara perusahaan dengan pihak, baik langsung maupun tidak langsung, mengendalikan atau dikendalikan oleh perusahaan tersebut; (e) hubungan antara dua perusahaan yang dikendalikan, baik langsung maupun tidak langsung, oleh pihak yang sama; atau (f) hubungan antara perusahaan dan pemegang saham utama.

${ }^{10}$ Lihat Pasal 1 huruf $d$ Peraturan Nomor IX.E. 1. Lihat pula Pasal 1 huruf a yang menyebutkan Perusahaan adalah Emiten yang telah melakukan Penawaran Umum Efek Bersifat Ekuitas atau Perusahaan Publik.

"Lihat Pasal 3 Peraturan Nomor IX.E.1. 
Pasar Modal, para pemegang saham dan semua karyawan. Transaksi tersebut termasuk pula manfaat yang diberikan oleh perusahaan atau perusahaan terkendali kepada semua karyawan, direksi atau komisaris dengan persyaratan yang sama, menurut kebijakan perusahaan yang disampaikan kepada Badan Pengawas Pasar Modal, para pemegang saham, dan semua karyawan.

5. penggunaan setiap fasilitas yang diberikan oleh perusahaan atau perusahaan terkendali kepada komisaris, direktur, dan pemegang saham utama yang juga karyawan yang langsung berhubungan dengan tanggung jawab mereka terhadap perusahaan tersebut dan sesuai dengan kebijakan perusahaan yang disampaikan kepada Badan Pengawas Pasar Modal. sebagai infomasi kepada masyarakat;

6. imbalan, termasuk gaji, iuran dana pensiun, dan atau manfaat khusus yang diberikan kepada komisaris, direktur dan pemegang saham utama yang juga sebagai karyawan, jika jumlah secara keseluruhan dari imbalan tersebut diungkapkan dalam laporan keuangan berkala; dan

7. pembelian tanah dan atau bangunan rumah tinggal dari seorang komisaris, direktur, dan pemegang saham utama, atau setiap pihak yang mereka ketahui terafiliasi dengan perusahaan pada saat itu dalam jumlah tidak lebih dari Rp 5.000 .000 .000 ; atau kurang dari $0,5 \%$ dari nilai kekayaan bersih perusahaan, sesuai dengan laporan keuangan terakhir yang diperiksa oleh Akuntan. Pembelian dimana terdapat benturan kepentingan dan yang jumlahnya lebih dari Rp 10.000.000.000; wajib dinilai oleh penilai independen.

8. transaksi yang dilakukan baik secara langsung maupun tidak langsung oleh Badan Penyehatan Perbankan Nasional dalam rangka restrukturisasi perusahaan dan pemulihan ekonomi nasional. ${ }^{12}$

Pemberitahuan Rapat Umum Pemegang Saham untuk menyetujui suatu transaksi (rencana transaksi) yang berbenturan dengan kepentingan, harus meliputi informasi sebagai berikut:

1. uraian mengenai transaksi sekurangkurangnya meliputi: kekayaan atau jasa yang bersangkutan; nilai transaksi yang bersangkutan; nama pihak-pihak yang mengadakan transaksi dan hubungan mereka dengan perusahaan yang bersangkutan; dan sifat dari benturan kepentingan pihak-pihak yang bersangkutan dalam transaksi tertentu;

2. ringkasan laporan pihak independen yang

${ }^{12}$ Badan Penyehatan Perbankan Nasional (BPPN) adalah lembaga khusus yang dibentuk oleh pemerintah, pada awal tahun 1998. Pendiriannya dilakukan untuk membantu memulihkan sektor perekonomian nasional melalui program penjaminan pemerintah, penyehatan perbankan serta restrukturisasi utang perusahaan. Masa tugas BPPN berakhir pada 27 Februari 2004. Sebagai badan pengganti BPPN, pemerintah mengeluarkan Peraturan Pemerintah Nomor 10 Tahun 2004 tentang Pendirian Perusahaan Persero di Bidang Pengelolaan Aset. Badan tersebut menjalankan tugas BPPN dalam hal merekstruturisasi aset, bekerja sama dengan pihak lain dalam rangka peningkatan nilai aset, penagihan piutang, dan penjualan. 
ditunjuk;

3. tanggal, waktu, dan tempat diselenggarakannya Rapat Umum Pemegang Saham dan rapat pemegang saham selanjutnya yang direncanakan akan diselenggarakan jika kuorum kehadiran pemegang saham independen yang dipersyaratkan tidak diperoleh dalam rapat pertama, pernyataan tentang persyaratan pemberian suara dalam rencana transaksi tersebut dan pemberian suara setuju yang disyaratkan dalam setiap rapat;

4. penjelasan pertimbangan dan alasan dilakukannya transaksi tersebut, dibandingkan dengan apabila dilakukan transaksi lain yang tidak mengandung benturan kepentingan;

5. rencana perusahaan, data perusahaan, dan informasi lain yang dipersyaratkan; ${ }^{13}$

6. persyaratan komisaris dan direktur yang menyatakan bahwa semua informasi material telah diungkapkan dan informasi tersebut tidak menyesatkan; dan

7. ringkasan laporan tenaga ahli atau konsultan independen jika dianggap perlu oleh Badan Pengawas Pasar Modal.

Suatu transaksi yang mengandung benturan kepentingan dapat dilakukan jika telah memperoleh persetujuan para pemegang saham independen dalam Rapat Umum Pemegang Saham yang dihadiri oleh pemegang saham independen yang mewakili lebih dari $50 \%$ saham yang dimiliki oleh pemegang saham independen dan transaksi dimaksud disetujui oleh pemegang saham independen yang mewakili lebih dari $50 \%$ saham yang dimiliki oleh pemegang saham independen. ${ }^{14}$ Jika kuorum Rapat Umum Pemegang Saham tidak dipenuhi, maka rapat kedua dapat mengambil keputusan dengan syarat kehadiran dan pengambilan keputusan sama dengan Rapat Umum Pemegang Saham pertama.

Apabila kuorum Rapat Umum Pemegang Saham yang kedua itupun belum terpenuhi, maka Rapat Umum Pemegang Saham yang kétiga hanya dapat dilakukan setelah memperoleh persetujuan dari Badan Pengawas Pasar Modal. Persetujuan tersebut didasarkan pada pertimbangan bahwa penyelenggaraan Rapat Umum Pemegang Saham tersebut telah memenuhi persyaratan, yaitu pengumuman kepada masyarakat telah dilaksanakan sesuai dengan ketentuan Rapat Umum Pemegang Saham yang pertama dan. kedua; dan tempat rapat serta prosedur pemberian kuasa telah dilaksanakan dengan memperhatikan kepentingan pemegang saham independen. Rapat Umum Pemegang Saham ketiga hanya dapat menyetujui transaksi yang mengandung benturan kepentingan jika disetujui oleh pemegang saham independen yang mewakili lebih dari

${ }^{13}$ Dalam hal transaksi material, perubahan kegiatan usaha utama atau pengambialihan perusahaan terbuka yang mengandung benturan kepentingan, maka Perusahaan harus pula memenuhi keterbukaan informasi sebagaimana diatur dalam Peraturan Nomor IX.E.2 tentang Transaksi Material dan Perubahan Kegiatan Usaha Utama atau Peraturan Nomor IX:H.1 tentang Pengambilalihan Perusahaan Terbuka. Lihat Pasal 7 Peraturan Nomor IX.E.1.

${ }^{14}$ Lihat Pasal 9 Peraturan Nomor IX.E.1 
$50 \%$ saham yang dimiliki oleh pemegang saham independen yang hadir.

Jika pemegang saham independen dalam Rapat Umum Pemegang Saham yang telah mencapai kuorum tidak menyetujui transaksi yang mengandung benturan kepentingan, maka transaksi tersebut tidak dapat diajukan kembali dalam jangka 12 bulan sejak tanggal keputusan penolakan. ${ }^{15}$

Kenyataannya, sebagian besar perusahaan publik di Indonesia masih dimiliki oleh perorangan atau institusi yang masih memiliki hubungan, baik hubungan keluarga maupun hubungan bisnis yang sangat erat. Fakta tersebut berakibat pada dominasi suara dalam Rapat Umum Pemegang Saham, termasuk Rapat Umum Pemegang Saham Independen, yang dikuasai pihak-pihak yang terafiliasi sehingga besar kemungkinannya. akan merugikan kepentingan saham publik (independen). ${ }^{16}$

\section{Pelanggaran terhadap Ketentuan Benturan Kepentingan Transaksi Tertentu}

Bentuk transaksi berbenturan kepentingan yang terjadi di pasar modal cukup beragam, misalnya perjanjian pembayaran utang, pemberian pinjaman kepada pihak yang memiliki hubungan istimewa, penjualan aset kepada pihak terafiliasi, pembatalan perjanjian jual beli, dan penjaminan utang.

Transaksi yang mengandung benturan kepentingan berupa perjanjian pembayaran utang (novasi) dilakukan oleh PT Super Mitory Utama Tbk. terhadap PT Multikarsa Investama. Sanksi yang dijatuhkan oleh Badan Pengawas Pasar Modal terhadap pelanggaran tersebut antara lain denda kepada PT Super Mitory Utama Tbk. sebesar Rp 500.000.000; memerintahkan perseroan untuk menyelenggarakan Rapat Umum Pemegang Saham Independen untuk meminta persetujuan pemegang saham independen atas transaksi yang mengandung benturan kepentingan tersebut. Perseroan diwajibkan pula untuk menanggung seluruh biaya registrasi saham dari pemegang saham independen dalam rangka implementasi perdagangan saham tanpa warkat (scripless trading). Direksi dan Komisaris dikenakan sanksi administratif berupa peringatan tertulis, dan mewajibkan Direksi dan Komisaris membayar ke kas negara uang sebesar Rp 250.000.000; sebagai konsekuensi dari kelalaian mereka dalam melaksanakan tugas dan kewajibannya sesuai dengan ketentuan yang berlaku. ${ }^{17}$

${ }^{15}$ Lihat Pasal 11 Peraturan Nomor IX.E.1.

${ }^{18}$ Robinson Simbolon, "Pentingnya Perubahan UU Nomor 8 Tahun 1995 tentang Pasar Modal (UUPM)," Jumal Hukum Bisnis (Jakarta: Yayasan Pengembangan Hukum Bisnis, Juli 2001), hlm 9.

${ }^{17}$ Badan Pengawas Pasar Modal, Press Release, http://www.bapepam.go.id/news/Agustus2000/PR-318-200.pdf., 31 Agustus 2000. PT Super Mitory Utama Tbk. juga melakukan pelanggaran prinsip keterbukaan di pasar modal berupa tidak menyampaikan Laporan Keuangan Tahunan Periode 31 Desember 1999 tepat pada waktunya. 
PT Dharmala Sakti Sejahtera Tbk. melanggar peraturan tentang transaksi yang mengandung benturan kepentingan ketika melakukan transaksi dengan PT Dharmala Inti Utama. Transaksi tersebut tidak pernah dimintakan persetujuan kepada pemegang saham independen dalam Rapat Umum Pemegang Saham. Sanksi denda sebesar Rp 500.000.000; dikenakan oleh Badan Pengawas Pasar Modal berkaitan dengan pelanggaran tersebut. ${ }^{18}$

Transaksi pemberian pinjaman sebesar Rp 10.000.000.000; oleh PT Asuransi Bina Dana Arta Tbk. kepada pihak yang memiliki hubungan istimewa yaitu PT Dharmala Sakti Sejahtera selaku pemegang $64 \%$ saham PT Asuransi Bina Dana Arta Tbk. tanpa persetujuan dari pemeganig saham independen. Sanksi administratif dan perintah untuk melakukan tindakan tertentu dikenakan kepada PT Asuransi Bina Dana Arta Tbk, yaitu Direksi dan Komisaris diwajibkan membayar ke kas negara sebesar Rp 500.000.000; karena lalai dalam memenuhi ketentuan sebagaimana dimaksud dalam. Peraturan IX.E.1. Perseroan diwajibkan melaksanakan Rapat Umum Pemegang Saham antara lain dengan agenda pemberitahuan kepada pemegang saham independen informasi pemberian pinjaman oleh perseroan kepada pihak yang memiliki hubungan istimewa sebesar Rp 10.000.000.000; PT Asuransi Bina Dana Arta Tbk. juga diwajibkan membayar biaya registrasi atas saham PT Asuransi Bina Dana Arta Tbk yang dimiliki oleh pemegang saham publik dalam rangka perdagangan tanpa warkat (scripless trading). ${ }^{19}$

PT Asia Inti Selera Tbk telah melakukan transaksi pemberian pinjaman tanpa mendapatkan persetujuan terlebih dahulu dari pemegang saham independen dalam Rapat Umum Pemegang Saham kepada pihak lain yang memiliki hubungan istimewa yaitu Cahyadi Kumala dan Jijin S. Japiarbudhi masing-masing sebesar $R p$ 165.000.000; dan Rp 341.000. 000.000; Badan Pengawas Pasar Modal memberikan sanksi administratif berupa denda sebesar Rp 500.000.000; dan kewajiban untuk mengagendakan terjadinya transakși pemberian pinjaman kepada pihak yang memiliki hubungan istimewa sebesar Rp 3.616.000.000; serta batas waktu penyelesaian piutang tersebut.20

Transaksi penjualan aset (aktiva tetap) kepada pihak terafiliasi dilakukan oleh PT Jaya Pari Steel Corp. Ltd. Tbk pada 13 Desember 2001 berupa tanah dan bangunan di Jalan Margomulyo Nomor 29A Surabaya kepada PT Gunawan Dianjaya Steel (pihak terafiliasi) dengan nilai Rp 29.300.000.000; Ternyata, penjualan aset tersebut belum mendapat persetujuan dari pemegang saham

${ }^{18}$ Ibid. PT Dharmala Sakti Sejahtera Tbk. juga telah melanggar prinsip keterbukaan di pasar modal berupa tidak menyampaikan Laporan Keuangan Tahunan Periode 31 Desember 1999 tepat pada waktunya.

${ }^{19}$ Badan Pengawas Pasar Modal, "Press Release", http://www.bapepam.go.id/news/Feb2001/rilis5-22001.pdf, 5 Februari 2001.

20 Badan Pengawas Pasar Modal, "Press Release", http://www.bapepam.go.id/news/Juni2002/ PR_18JUN.PDF, 18 Juni 2002. PT Asia Inti Selera Tbk juga dinyatakan melanggar Peraturan Nomor X.K.4 tentang Laporan Realisasi Penggunaan Dana Hasil Penawaran Umum. 
independen dalam Rapat Umum Pemegang Saham. Sanksi yang diberikan Badan Pengawas Pasar Modal adalah sanksi administratif berupa denda Rp 500.000.000; dan kewajiban mengagendakan pertanggungjawaban dan penyampaian informasi adanya penjualan aset tersebut kepada Rapat Umum Pemegang Saham berikutnya. ${ }^{21}$

Kasus pelanggaran benturan kepentingan transaksi tertentu berupa pembatalan perjanjian jual beli tanpa melalui persetujuan pemegang saham independen dilakukan oleh PT Jakarta International Hotels \& Development Tbk. Kasus ini bermula dari adanya informasi yang diberikan oleh sindikasi kreditor asing PT Jakarta International Hotels \& Development Tbk pada 30 April 2002. Setelah dilakukan pemeriksaan dan penelaahan terhadap data dan para pihak. terkait menunjukkan PT Danayasa Arthatama Tbk selaku anak perusahaan PT Jakarta International Hotels \& Development Tbk telah melakukan transaksi pembatalan perjanjian jual beli pada 15 Juni 2001 berupa pembelian kembali tanah pada Lot 18, 19, dan 20 Kawasan Niaga Terpadu Sudirman untuk dikelola kembali oleh PT Graha Putrasentosa, PT Panduneka Abdi dan PT Citra Wiradaya (anak perusahaan PT Danayasa Arthatama Tbk) dengan nilai Rp 315.000.000.000; dari PT Bank Artha Graha. Sanksi yang dikenakan oleh Badan Pengawas Pasar Modal berupa denda sebesar Rp 500.000.000; dan kewajiban membayar Rp 500.000.000; oleh Direksi dan Komisaris PT Jakarta International Hotels \& Development Tbk, karena tindakannya telah menyetujui pembatalan perjanjian tersebut yang berpotensi merugikan PT Jakarta International Hotels \& Development Tbk. ${ }^{22}$

Transaksi penjaminan utang dilakukan oleh PT Multipolar Corporation Tbk tanpa melakukan Rapat Umum Pemegang Saham independen. Kasus ini berawal dari penjaminan deposito milik PT Multipolar Corporation Tbk sebesar US $\$ 2.000 .000$ sebagai jaminan utang PT Broadband Multimedia di Bank Lippo tahun 2000 yang jatuh temponya tahun 2001, dan diperpanjang sampai $12 \mathrm{Mei}$ 2002, dan jaminan Rp 17.380.000.000; pada Juni 2000 yang jatuh tempo pada 2001, dan diperpanjang sampai 12 Mei 2002. Jaminan deposito juga diberikan kepada PT Broadband di Bank Mayapada sebesar US $\$ 0,3$ juta sebagai jaminan utang pada Mei 2000 yang jatuh tempo pada 2001 diperpanjang sampai 11 Nopember 2002, dan pinjaman sebesar Rp 10.000.000.000; November 2001 yang jatuh tempo pada 11 Nopember 2002. ${ }^{23}$

Badan Pengawas Pasar Modal menetapkan sanksi kepada PT Multipolar Corporation Tbk sebesar Rp 500.000.000; dan menetapkan sanksi kepada Direksi dan Komisaris berupa kewajiban membayar Rp 500.000 .000 ; karena tindakannya tidak cukup hati-hati dalam mengelola perusahaan berkaitan dengan penjaminan yang diberikan

21 Ibid.

22 Badan Pengawas Pasar Modal, "Press Release", http:/www.bapepam.go.id/news/Nop2002/ ReleaseNov.pdf., 8 November 2002.

${ }^{23} \mathrm{lbid}$. 
atas utang PT Broadband Multimedia Tbk. Badan Pengawas Pasar Modal juga memberikan sanksi terhadap PT Broadband Multimedia Tbk sebesar Rp 500.000.000,24

\section{Mencermati Penjatuhan Sanksi oleh Badan Pengawas Pasar Modal}

Paparan mengenai pelanggaran benturan kepentingari transaksi tertentu di atas menunjukkan perseroan yang terlibat dengan benturan kepentingan transaksi tertentu tidak semuanya mendapatkan sanksi. Meskipun bentuk pelanggaran dan besarnya jumlah transaksi sangat bervariatif, namun Badan Pengawas Pasar Modal memberikan sanksi yang sama terhadap perseroan berupa sanksi denda sebesar Rp 500.000:000;

Penjatuhan sanksi yang dilakukan Badan Pengawas Pasar Modal tersebut, mengesankan adanya ketidakadilan perlakuan terhadap perseroan maupun direksi dan komisaris yang melakukan pelanggaran ketentuan benturan kepentingan transaksi tertentu. Padahal sanksi dalam UndangUndang Nomor 8 Tahun 1995 tentang Pasar Modal sangat variatif, yaitu peringatan tertulis, denda atau kewajiban untuk membayar sejumlah uang tertentu, pembatasan kegiatan usaha, pembekuan kegiatan usaha, pencabutan izin usaha, pembatalan persetujuan, dan pembatalan pendaftaran. ${ }^{25}$ Sanksi denda terhadap perseorangan yang melakukan benturan kepentingan transaksi tertentu sebesar Rp 100.000.000; sedangkan kepada perusahaan sebesar $R p$ $500.000 .000 ;{ }^{26}$

Mencermati lebih jauh beberapa pelanggaran ketentuan benturan kepentingan transaksi tertentu, nampak bahwa tidak semua direksi maupun komisaris menerima sanksi dari Badan Pengawas Pasar Modal. Dari tujuh pelanggaran, hanya 4 direksi yang dikenakan sanksi dan komisaris berupa pembayaran denda, yaitu PT Super Mitory Utama Tbk., sebesar Rp 250.000.000; PT Asuransi Bina Dana Arta Tbk sebesar Rp 500.000.000; PT Jakata International Hotels \& Development Tbk sebesar Rp 500.000.000; dan PT Multipolar Corporation Tbk sebesar $R p$ 500.000.000;

Keempat direksi maupun komisaris yang dikenakan sanksi oleh Badan Pengawas Pasar Modal tersebut sebagai konsekuensi dari kelalaian dalam melaksanakan tugas dan kewajibannya sesuai dengan ketentuan yang berlaku; tindakan direksi maupun komisaris dinyatakan tidak cukup hati-hati dalam mengelola perusahaan, dan menyetujui pembatalan suatu perjanjian yang berpotensi merugikan perusahaan.

Pelanggaran yang dilakukan direksi dan komisaris tersebut dilihat dari hukum perusahaan termasuk sebagai pelanggaran terhadap doktrin duty of care, business judgement rule, dan ultra vires. Setiap direksi maupun

$24 \mathrm{bid}$

${ }^{25}$ Lihat Pasal 102 Undang-Undang Nomor 8 Tahun 1995 tentang Pasar Modal

${ }^{28}$ Lihat Pasal 65 Peraturan Pemerintah Nomor 45 Tahun 1995 tentang Penyelenggaraan Kegiatan di Bidang Pasar Modal. 
komisaris wajib dengan iktikad baik dan penuh. tanggung jawab menjalankan tugas untuk kepentingan dan usaha perseroan. ${ }^{27}$ UndangUndang Nomor 1 Tahun 1995 tentang Perseroan Terbatas maupun yurisprudensi Indonesia belum menampilkan makna "iktikad baik dan penuh tanggung jawab" sebagaimana dimaksud dalam UndangUndang Nomor 1 Tahun 1995 tentang Perseroan Terbatas..$^{28}$ Di negara-negara common law system, acuan yang dipakai adalah standar kehati-hatian (standard of care). Jika direksi bersikap dan bertindak melanggar standard of care, maka direksi dianggap telah melanggar duty of care. ${ }^{29}$

Business judgement rule doctrine merupakan kebalikan dari duty of care doctrine. Para anggota direksi tidak dapat dibebani tanggung jawab atas akibat-akibat yang timbul karena telah dilakukannya pertimbangan bisnis (business judgement) oleh anggota direksi tersebut, sekalipun apabila pertimbangan itu keliru, kecuali dalam hal-hal tertentu. Hal-hal tertentu tersebut antara lain pertimbangan bisnis didasarkan atas suatu kecurangan (fraud), atau menimbulkan benturan kepentingan (conflict of interest), atau merupakan perbuatan yang melanggar hukum (illegality), atau kerugian yang terjadi sebagai akibat kelalaian berat (gross negligence) anggota direksi yang bersangkutan. ${ }^{30}$

Dalam melaksanakan tugas atau kewajibannya (fiduciary duties), direksi maupun komisaris dilarang melakukan kegiatan yang berada di luar kewenangannya atau yang dikenal dengan ultra vires. Doctrine of ultra vires dapat ditemukan dalam Pasar 2 Undang-Undang Nomor 1 Tahun 1995 tentang Perseroan Terbatas. Perseroan tidak diperkenankan melakukan kegiatan yang tidak sejalan dengan maksud dan tujuan perseroan. Jika hal itu dilakukan, maka perseroan telah melakukan perbuatan yang ilegal. ${ }^{31}$

Secara garis besar, tindakan Badan Pengawas Pasar Modal dalam menjatuhkan sanksi terhadap perseroan, direksi dan komisaris yang terlibat dengan benturan kepentingan transaksi tertentu telah sesuai dengan prinsip-prinsip yang ada dalam Undang-Undang Nomor 1 Tahun 1995 tentang Perseroan Terbatas dan UndangUndang Nomor 8 Tahun 1995 tentang Pasar Modal, beserta peraturan pelaksanaannya. Namun demikian, sanksi tersebut masih

${ }^{27}$ Lihat Pasal 85 ayat (1) juncto Pasal 98 ayat (1) Undang-Undang Nomor 1 Tahun 1995 tentang Perseroan Terbatas.

${ }^{28}$ Sutan Remy Sjahdeini, "Tanggung Jawab Pribadi Direksi dan Komisaris" Jumal Hukum Bisnis (Jakarta: Yayasan Pengembangan Hukum Bisnis, Juli 2001), hlm 100.

${ }^{29} \mathrm{lbid}$. Contoh standard of care antara lain anggota direksi dilarang melakukan kegiatan atas beban biaya perseroan, jika tidak membawa manfaat bagi perseroan; anggota direksi tidak boleh menjadi pesaing bagi perseroan yang dipimpinnya; anggota direksi harus menolak mengambil keputusan mengenai sesuatu hal yang diketahuinya atau sepatutnya diketahuinya dapat mengakibatkan melanggar perałuran perundang-undangan yang berlaku; anggota direksi dengan sengaja atau karena kelalaiannya tidak melakukan tindakan untuk mencegah kerugian bagi perseroan, atau tindakan untuk meningkatkan keuntungan perseroan.

${ }^{30}$ Ibid., hlm 101.

${ }^{31}$ Ibid., hlm 103. 
Siti Anisah. Benturan Kepentingan Transaksi Tertentu ...

belum maksimal, dan ada perbedaan perlakuan terhadap para pihak yang terkait dengan benturan kepentingan transaksi tertentu.

\section{Simpulan}

Peraturan yang melindungi para pihak yang dirugikan berkaitan dengan benturan kepentingan transaksi tertentu telah cukup memadai, baik dari undang-undang teriebih peraturan Badan Pengawas Pasar Modal, yang secara konsisten memperbarui peraturan yang ada disesuaikan dengan perkembangan kebutuhan dalam masyarakat. Prakteknya, aturan tersebut belum diimplementasikan secara maksimal. Meskipun Badan Pengawas Pasar Modal telah berusaha menjatuhkan sanksi sesuai dengan ketentuan yang ada, namun sanksi tersebut belum maksimal dan terdapat perlakuan yang berbeda terhadap perseroan, direksi maupun komisaris yang terlibat benturan kepentingan transaksi tertentu.

\section{Daftar Pustaka}

Badan Pengawas Pasar Modal, "Press Release", http://www.bapepam.go.idl news/Juni2002/PR 18JUN.PDF_18 Juni 2002.

"Press Release", http:/l/ www.bapepam.go.id/news/Feb2001/ rilis5-2-2001.pdf, 5 Februari 2001.

"Press Release", http:II www.bapepam.go.id/news/Nop20021 ReleaseNov.pdf., 8 November 2002. "Press Release Penyempumaan
Peraturan Bapepam"

Tentang Benturan Kepentingan Transaksi Tertentu" http://www.bapepam.go.id/ news/Agutus2000/PR 23 08.htm, 23 Agustus 2000.

- _ _-, Press Release, http:// www.bapepam.go.id/news/ Agustus2000/PR-31-8-200.pdf.. 31 Agustus 2000.

Nasarudin, M. Irsan, dan Indra Surya, Aspek Hukum Pasar Modal Indonesia, Jakarta: Prenada Media, 2004.

Nasution, Bismar, Keterbukaan dalam Pasar Modal, Jakarta: Fakultas Hukum, Program Pascasarjana Universitas Indonesia, 2001.

Peraturan Badan Pengawas Pasar Modal Nomor IX.E.1 tentang Benturan Kepentingan Transaksi Tertentu.

Peraturan Pemerintah Nomor 45 Tahun 1995 tentang Penyelenggaraan Kegiatan di Bidang Pasar Modal.

Shook, R.J., "Wall Street Dictionary", Alih Bahasa Roy Sembel, Kamus Lengkap Keuangan Wall Street, Jakarta: Erlangga, 2002.

Simbolom, Robinson, "Pentingnya Perubahan UU Nomor 8 Tahun 1995 tentang Pasar Modal (UUPM)," Jumal Hukum Bisnis, Jakarta: Yayasan Pengembangan Hukum Bisnis, Juli 2001.

Sjahdeini, Sutan Remy, "Tanggung Jawab Pribadi Direksi dan Komisaris" Jurnal Hukum Bisnis, Jakarta: Yayasan Pengembangan Hukum Bisnis, Juli 2001. 
Sugarda, Paripurna P., "Pengelolaan

Bisnis, Julii 200.

Perusahaan yang Baik: Apakah Hanya

Etika Bisnis atau Juga Persyaratan

Hukum?" Jumal Hukum Bisnis, Jakarta:

Undang-Undang Nomor 8 Tahun 1995

Yayasan Pengembangan Hukum

tentang Pasar Modal.

व 